\title{
НАПРЯМКИ ТРАНСФОРМАЦІЇ ЕКОНОМІЧНОЇ СИСТЕМИ УКРАЇНИ В УМОВАХ СЬОГОДЕННЯ
}

\section{UKRAINIAN ECONOMIC SYSTEM TRANSFORMATION DIRECTIONS WITHIN THE EXISTING CIRCUMSTANCES}

\author{
Табачук Андрій Ярославович \\ кандидат економічних наук, \\ Львівський національний університет імені Івана Франка \\ ORCID: https://orcid.org/0000-0003-0120-2336
}

Tabachuk Andrii

Ivan Franko Nationality University of Lviv

\begin{abstract}
У статті висвітлено сучасний стан економіки України. На основі статистичних матеріалів висловлено переконання, що у вітчизняній економічній системі простежуються кризові тенденції. Виокремлено ключові причини наявності економічної кризи в Україні. Висловлено переконання, що перспективним напрямком подолання кризових тенденцій в економічній системі України є їі трансформація. Під трансорормацією соціально-економічної системи України запропоновано розуміти взаємопов'язані зміни економічних, соціальних і політичних структур суспільства, котрі у своїй сукупності покликані сорормувати соціально-економічну та політичну модель суспільства. Виділено «вузькі» місця у процесі трансфрормації економічної системи України. Досліджено, що ключовими векторами трансорормації економічної системи України є: удосконалення макроекономічної політики, досягнення верховенства права, створення еорективного регуляторного середовища, сприяння розвитку промисловості, сприяння росту інституційної спроможності органів місцевого самоврядування і стимулювання діджиталізації економіки України.
\end{abstract}

Ключові слова: економічна система, трансорормаційний процес, стійкий розвиток, конкурентоспроможність економіки, глобалізація, постіндустріальне суспільство.

В статье освещено современное состояние экономики Украины. На основе статистических материалов высказано убеждение, что в отечественной экономической системе прослеживаются кризисные тенденции. Выделены ключевые причины наличии экономического кризиса в Украине. Высказано убеждение, что перспективным направлением преодоления кризисных тенденций в экономической системе Украины является ее трансформация. Под трансформацией социально-экономической системы Украины предложено понимать взаимосвязанные изменения экономических, социальных и политических структур общества, которые в своей совокупности призваны сорормировать социально-экономическую и политическую модель общества. Выделены «узкие» места в процессе трансоромации экономической системы Украины. Доказано, что ключевыми векторами трансформации экономической системы Украины является: совершенствование макроэкономической политики, достижения верховенства права, создание эффрективной регуляторной среды, содействие развитию промышленности, содействие росту институциональной способности органов местного самоуправления и стимулирования диджитализации экономики Украины.

Ключевые слова: экономическая система, трансформационный процесс, устойчивое развитие, конкурентоспособность экономики, глобализация, постиндустриальное общество.

The purpose of the article is to highlight the vectors of transformation of the social and economic system of Ukraine in order to move to a qualitatively new stage of sustainable development. Topic actuality. Analysis of the current stage of the Ukrainian economic system development visualizes the presence of a number of recessionary tendencies that negatively affect its competitiveness on the international stage. The level of economic stability of the domestic economic system is influenced by many factors, among which it is appropriate to highlight both immediate economic and political and social, which are largely related to military aggression by the Russian Federation and the COVID-19 pandemic. The presence of obstacles to the sustainable development of the domestic economic system under the current conditions of its operation encourages the search for perspectives for development of the Ukrainian economic system. The results obtained. On the basis of statistical materials, the opinion that recessionary tendencies can be observed in the domestic economic system is expressed. The primary causes for the economic crisis in Ukraine are identified. The opinion that a promising way to overcome recessionary tendencies in the economic 
system of Ukraine is its transformation is expressed. 'Bottlenecks' in the process of transformation of the economic system of Ukraine have been identified. It is proved that the key vectors of transformation of the Ukrainian economic system are the following: macroeconomic policy development, the rule of law achievement, effective regulatory environment creation, industrial promotion, institutional capacity of local governments promotion and Ukrainian economy digitalization encouragement. The article practical value. A comprehensive approach to the transformation of the Ukrainian economic system in the following major areas will afford the opportunity to stimulate economic growth, improve the lives of the population and lay the foundation for sustainable development in the long run. An important factor in the successful economic system transformation process according to the proposed vectors is the national unification and strategic reform, which will respect the interests of all stakeholders. Unity of ideas and solidarity of purpose, primarily among the ruling establishment, is the key to the effectiveness of reform in general.

Keywords: economic system, transformation process, sustainable development, economic competitiveness, globalization, post-industrial society.

Постановка проблеми. Сьогоднішній етап розвитку економічної системи України характеризується низьким рівнем економічної стійкості, котрий зумовлений низкою проблем, серед яких доцільно виділити як безпосередньо економічні, так і політико-соціальні, що у великій мірі пов'язані $з$ військовою агресією з боку Російської Федерації та пандемією COVID-19.

Наявність перешкод на шляху стійкого розвитку вітчизняної економічної системи у сучасних умовах її фрункціонування спонукає до пошуку перспективних напрямків розвитку економічної системи України.

У даному контексті, ключовою проблемою, на наше переконання, $€$ не лише пошук способів виходу 3 наявної кризи, а й продукування ідей щодо напрямів трансорормації економічної системи України 3 метою покращення їі стійкості та конкурентоспроможності у стратегічній перспективі.

Аналіз останніх досліджень і публікацій. У розв'язанні проблеми транссрормації економічних систем вагому наукову цінність несуть праці таких вітчизняних та зарубіжних науковців як: Л. Абалкіна, О. Бузгаліна, Е. Тофрфлера, В. Геєця, А. Чухна, П. Леоненка, О. Орловської, О. Громико, Н. Гражевської, Л. Потравки, В. Зубенка, І. Мельника, А. Дьяченка, Г. Івлєва, О. Удалова та інших.

Виділення невирішених раніше частин загальної проблеми. Попри вагому значущість та нагальність питання подолання кризових явищ у економічній системі України, проблема трансформації економічної системи, як безпосередня можливість покращення соціально-економічного становища в наші країні, розкривається у науковій літературі, як правило, крізь призму окремих секторів економіки. Комплексний підхід до вирішення даної проблеми покликаний розкрити у повній мірі існуючі негативні тенденції, що стоять на шляху трансорормаційних перетворень та дозволить виділити основні напрямки трансорормації соціально-економічної сис- теми України, котрі на думку автора у стратегічній перспективі зумовлять стійкий розвиток вітчизняної соціально-економічної системи.

Формулювання цілей статті (постановка завдання). Ключовою ціллю статті $€$ висвітлення напрямків трансорормації соціальноекономічної системи України як запоруки її стійкого розвитку та покращення конкурентоспроможності на світовій арені.

Виклад основного матеріалу дослідження. За даними Державної служби статистки України вітчизняна економіка завершила 2020 рік 3 такими результатами (відношення до відповідного періоду попереднього року): реальний ВВП знизився на 4\%; обсяг промислового виробництва скоротився на 4,2\%; обсяг продукції сільського господарства зменшився на 6,1\%; капітальні інвестиції скоротилися на 38,2\%; експорт товарів та послуг зменшився на 7,8\%; імпорт товарів та послуг скоротився на 12,5\% [8].

В структурі валової доданої вартості у 2020 році промисловість займала 21\%, торгівля - 16,3\%, сільське господарство $10,8 \%$, транспорт - 7,3\%, будівництво - 3,3\% (див. рис. 1) [8].

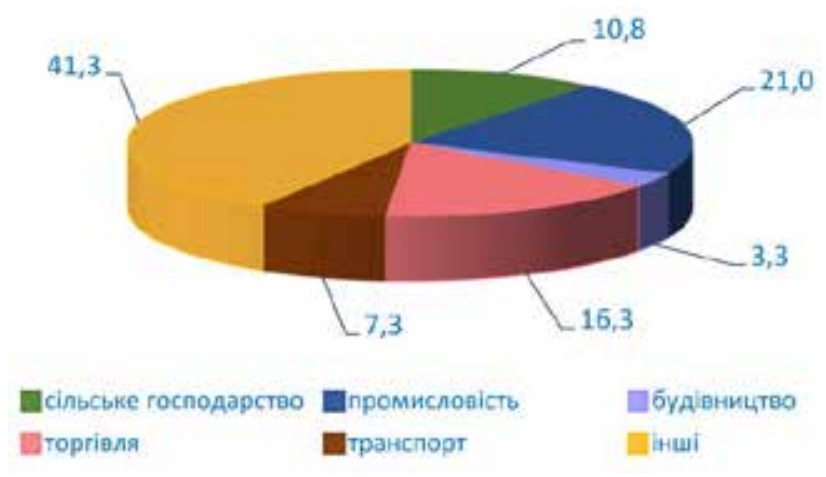

Рис. 1. Структура валової доданої вартості у 2020 році, \% [8]

Наведена вище інорормація яскраво ілюструє наявність в Україні кризових тенденцій у ключових сорерах суспільного виробництва. 
Говорячи про кризовість наявної ситуації в економіці України слід, в першу чергу, виявити чим вона зумовлена. Поділяємо думку, що одними 3 ключових груп причин існування кризових явищ у вітчизняній економіці $\epsilon$ наступні:

1. причини, що перейшли в національну економіку із розпадом СРСР;

2. не до кінця обдумане та у великій мірі провальне управління соціально-економічними процесами недосвідченими представниками влади;

3. причини, зумовлені необхідністю проведення прогресивних ресорм, котрі б дозволили трансфрормувати економіку у сучасне економічне суспільство світової економіки [6, c. 200].

Говорячи про сьогодення, окрім перелічених груп причин існування кризових явищ в економіці України, вважаємо за необхідне закцентувати увагу на найбільш гострих чинниках, що слугують дестабілізуючими фракторами у процесі розвитку вітчизняної економічної системи, а саме на впливі військової агресії з боку Російської Федерації та пандемiї COVID-19.

Війна, котра з 2014 року не вщухає на українському Донбасі розвалила економіку даного регіону та вкрай негативно впливає на економіку України. Як ринкові зв'язки, так і канали постачання зруйновано. Гігантські підприємства на окупованих територіях масово скоротили робочі місця або розвалились. Цілі громади загрузли в злиднях, які нині посилюються кризою COVID-19, котра і сама по собі приносить колосальні втрати для української економіки [1].

Попри досить невтішну ситуацію, ми переконані, що її можна покращити, перейти на шлях стійкого розвитку, але це вимагає докладання значних зусиль, спрямованих на трансформацію економічної системи України.

Поняття «трансорормація» вирізняється багатогранністю та має у науковій літературі велику кількість трактувань. В найширшому значенні під трансорормацією розуміють зміну, перетворення виду, фрорми, істотних властивостей і таке інше чого-небудь [9]. 3 економічної точки зору поняття «транссрормація» трактується як процес подолання істотних елементів старого порядку та фрормування якісно нового стану економічної системи [4, с. 126]. У науковій літературі дане поняття почало активно використовуватись у другій половині XX століття, з метою характеристики процесів, що були пов'язаними зі структур- ними змінами національних економік та переходом людства на новий, постіндустріальний, етап свого розвитку.

Розважаючи над проблемою довгострокових перспектив розвитку вітчизняної економіки та об'єктивною необхідністю її трансформації, приходимо до висновку, що основою, базовими чинниками, підвищення конкурентоспроможності економічної системи України виступають обґрунтування та реалізація ключових пріоритетів стратегічного розвитку національної економіки.

У даному контексті поділяємо думку Н. Гражевської, котра виділяє низку моментів, які слід врахувати при обґрунтуванні стратегічних пріоритетів розвитку національної економіки, ключовими серед яких $є$ :

1. не слід розглядати в лінійній площині трансорормаційні процеси в Україні, адже трансформаційна економіка нашої країни розвивається не стільки шляхом тотального руйнування старої економічної системи, скільки шляхом ускладнення вже існуючої економічної структури;

2. інверсійний тип перехідної економіки України, котрий пов'язаний з перестановкою в черговості різного роду економічних перетворень в зіставленні з їх так званим природним порядком, зумовлює пріоритетне значення інституційних змін у процесі ринкової транссрормації;

3. аналізувати процес системних перетворень в Україні слід у контексті діалектичної єдності загального, особливого та одиничного у трансорормаційному процесі, тобто, необхідно аналізувати взаємопов'язаність глобальних та локальних перетворень на шляху трансорормації економічної системи України [3, с. 235-237].

Доцільно зауважити, що процес визначення результативності моделі трансорормації економічної системи України $€$ досить складним, що зумовлено короткостроковою дією впливів зовнішніх фракторів та внутрішніх суб'єктів, практично відсутньою є системність та передбачуваність, а очікуваних результат, як правило, обмежується. Перелічене у свої сукупності приводить до короткостроковості очікуваного результату та підпорядкованості його інтересам окремих суб'єктів, що у свою чергу, зменшує можливості виходу національної економічної системи на шлях самоорганізації у рамках правого поля та на засадах публічності [7, с. 146].

Під трансформацією соціально-економічної системи України розуміють взаємопов'язані 
революційні та еволюційні зміни економічних, соціальних і політичних структур суспільства, котрі покликані сорормувати соціально-економічну та політичну модель суспільства, яка б сприяла задоволенню економічних, соціальних і політичних потреб громадян країни та забезпечувала б гідне місце країни на міжнародній арені в умовах посилення глобалізаційних процесів та становлення постіндустріального суспільства [5, с. 37].

Відправною точкою для розробки Національної економічної стратегії України 2030 став Аудит економіки держави, результати якого було представлено 6 листопада 2020 року. Проведений аудит виявив низку векторів економічного розвитку України до 2030 року. Виходячи з отриманих результатів, виокремимо основні, на наше переконання, напрямки трансформації економічної системи України, котрі покликані сприяти її стійкому розвитку:

1. Удосконалення макроекономічної політики. Макроекономічна політика повинна позиціонувати Україну як країну 3 ефрективними публічними орінансами та розвиненим фрінансовим сектором, котрі сприяють економічному зростанню. Першочерговими завданнями тут виступають наступні:

- залучення іноземних та стимулювання внутрішніх інвестицій, а також підвищення ефективності державних капіталовкладень;

- збільшення ефективності використання публічних орінансів;

- стимулювання експорту товарів та послуг;

- покращення купівельної спроможності населення України шляхом стимулювання економічного розвитку та покращення добробуту.

2. Верховенство права: сприяння тому, щоб Україна стала правовою державою, котра забезпечує права і свободи людини, право власності, відстоює справедливість та інтереси суспільства.

3.Створення ефрективного регуляторного середовища, що не здійснює тиску на бізнес та стимулює ведення підприємницької діяльності.

4. Покращення репутації України в очах зацікавлених груп.
5. Сприяння розвитку промисловості, як каталізатора економічного зростання та запоруки сталого розвитку.

6. Сприяння росту інституційної спроможності органів місцевого самоврядування та надати їм необхідні інструменти 3 метою забезпечення розвитку регіонів та підвищення рівня життя населення.

7. Стимулювання діджиталізації економіки України, так як циоррова економіка $є$ сорерою, котра визначає суть трансформацій в країні - для кращого життя, роботи, творчості та навчання [2].

Вважаємо, що комплексний підхід до трансформації економічної системи України за такими основними напрямками стимулюватиме економічне зростання, покращить життя населення та закладе фрундамент стійкого розвитку у довгостроковій перспективі. Важливим фрактором успішного проходження процесу транссрормації економічної системи за наміченими векторами полягає загальнонаціональному об'єднанні та стратегічному ресормуванні.

Висновки. Отже, в економіці України яскраво простежуються кризові тенденції. Кризовість ситуації зумовлена низкою причин, серед яких вагоме місце посідають військові дії на Сході країни та пандемія COVID19. Потенційним шляхом виходу з кризи $€$ трансформація економічної системи України, котра попри складність реалізації у зв'язку 3 низкою об'єктивних та суб'єктивних фракторів, дозволить покращити конкурентоспроможність вітчизняної економіки та сприятиме покращенню добробуту населення. Ключовими векторами трансорормації соціальноекономічної системи України, на наше переконання, $є$ удосконалення макроекономічної політики, досягнення верховенства права, створення ефрективного регуляторного середовища, сприяння розвитку промисловості та росту інституційної спроможності органів місцевого самоврядування і стимулювання діджиталізації економіки України.

Перспективним напрямом подальших досліджень виступає розробка дієвих заходів подальшої трансорормації економічної системи України в умовах гібридної війни та євроінтеграційних прагнень України.

СПИСОК ВИКОРИСТАНИХ ДЖЕРЕЛ:

1. Peace in Ukraine (III): The Costs of War in Donbas. Europe Report $N^{\circ} 26$. URL: https://d2071andvip0wj. cloudfront.net/261-peace-in-ukraine-iii-the-costs-of-war.pdf

2. Вектори економічного розвитку 2030. Матеріали для обговорення. URL: https://nes2030.org.ua/docs/docvector.pdf 
3. Гражевська Н.І. Еволюція економічних систем : навч. посіб. Київ : Знання, 2011. 286 с.

4. Громико О. Зміст поняття «трансфрормація» як базової наукової категорії. Ефрективність державного управління. 2016. Вип. 1/2 (46/47). С. 125-131.

5. Мельник І.М. Логіка та особливості трансформації економічної системи України. Торгівля, комерція, підприємництво. 2010. Вип. 11. С. 36-39. URL: http://nbuv.gov.ua/UJRN/Torg_2010_11_10

6. Орловська О.В. Світові економічні кризи: причини виникнення, наслідки та шляхи подолання. Науковий вісник національного лісотехнічного університету України : збірник наук.-техн. праць. Львів, 2015. Вип. 25.2. С. 197-202.

7. Потравка Л.О. Зубенко В.В. Результативність публічного правління транссоормацією економічної системи України. ДондУУ «Менеджер». 2020. № 1(86). С. 143-154.

8. Соціально-економічний розвиток України за січень-лютий 2021 року. URL: http://www.ukrstat.gov.ua/ operativ/infografika/2021/soc_ek_r_Ukr/-soc_ek_r_Ukr_02_21.pdf

9. Транссормація. URL: https://slovnyk.ua

\section{REFERENCES:}

1. Peace in Ukraine (III): The Costs of War in Donbas (2020). Europe Report N²6. URL: https://d2071andvip0wj. cloudfront.net/261-peace-in-ukraine-iii-the-costs-of-war.pdf

2. Vektory ekonomichnoho rozvytku 2030. Materialy dlya obhovorennya (2020) [Vectors of economic development 2030. Materials for discussion]. URL: https://nes2030.org.ua/docs/doc-vector.pdf (in Ukrainian)

3. Hrazhevs'ka N.I. (2011). Evolyutsiya ekonomichnykh system [Evolution of economic systems]. Kiev: Knowledge. (in Ukrainian)

4. Hromyko O. (2016). Zmist ponyattya «transformatsiya» yak bazovoyi naukovoyi katehoriyi [The content of the concept of "transformation" as a basic scientific category]. Efektyvnist' derzhavnoho upravlinnya - Efficiency of public administration, 1/2 (46/47), 125-131. (in Ukrainian)

5. Mel'nyk I.M. (2010). Lohika ta osoblyvosti transformatsiyi ekonomichnoyi systemy Ukrayiny [Logic and features of transformation of the economic system of Ukraine]. Torhivlya, komertsiya, pidpryyemnytstvo - Trade, commerce, entrepreneurship, 11, 36-39. URL: http://nbuv.gov.ua/UJRN/Torg_2010_11_10 (in Ukrainian)

6. Orlovs'ka O.V. (2015). Svitovi ekonomichni kryzy: prychyny vynyknennya, naslidky ta shlyakhy podolannya. [Global economic crises: causes, consequences and ways to overcome]. Naukovyy visnyk natsional'noho lisotekhnichnoho universytetu Ukrayiny - Scientific Bulletin of the National Forestry University of Ukraine, 25.2, 197-202. (in Ukrainian)

7. Potravka L.O., Zubenko V.V. (2020). Rezul'tatyvnist' publichnoho pravlinnya transformatsiyeyu ekonomichnoyi systemy Ukrayiny [The effectiveness of public governance in the transformation of the economic system of Ukraine]. Menedzher - Manager, 1(86), 143-154. (in Ukrainian)

8. Sotsial'no-ekonomichnyy rozvytok Ukrayiny za sichen'-lyutyy 2021 roku (2021) [Socio-economic development of Ukraine in January-February 2021]. URL: http://www.ukrstat.gov.ua/operativ/infografika/2021/soc_ek_r_ Ukr/-soc_ek_r_Ukr_02_21.pdf (in Ukrainian)

9. Transformatsiya [Transformation]. URL: https://slovnyk.ua (in Ukrainian) 